\title{
Application of gene probes to detect a penaeid shrimp baculovirus in fixed tissue using in situ hybridization
}

\author{
Linda D. Bruce ${ }^{1}$, Rita M. Redman ${ }^{1}$, Donald V. Lightner ${ }^{1, *}$, Jean-Robert Bonami ${ }^{2}$ \\ ${ }^{1}$ Department of Veterinary Science, University of Arizona, Tucson, Arizona 85721, USA \\ ${ }^{2}$ Laboratoire de Pathologie Comparée, Universite Montpellier Sciences et Techniques du Languedoc, CP 104, Place Eugene \\ Bataillon, F-34095 Montpellier Cedex 5, France
}

\begin{abstract}
DNA inseris obtained from a cloning of the penaeid shrimp baculovirus, BP, were nonradioactively labelled with digoxigenin for use as gene probes to detect BP in paraffin-embedded, formalin/alcohol-fixed tissue sections using in situ hybridization. Results show that the probes detect $\mathrm{BP}$ in various species of shrimp from different geographical areas. The probes demonstrate no reaction to $\mathrm{BP}$-negative tissue sections. The probes also demonstrate no reaction to tissue infected with other penaeid shrimp viruses.
\end{abstract}

KEY WORDS: Baculovirus penaei. BP Gene probes In situhybridization Penaeid shrimp PVSNPV

\section{INTRODUCTION}

A baculovirus infecting penaeid shrimp was first reported by Couch $(1974 a)$ in wild populations of Penaeus duorarum from the northern Gulf of Mexico. Originally named Baculovirus penaei (Couch 1974b), it has recently been proposed to be redesignated PVSNPV (for the most characterized variant, from $P$. vannamei, in the singly enveloped nuclear polyhedrosis virus group) by J. R. Bonami, L. D. Bruce, B. T. Poulos \& D. V. Lightner (unpubl.) according to the guidelines for virus nomenclature as set forth by the International Committee on the Taxonomy of Viruses (ICTV). For the purposes of this paper, the virus will be referred to by its common acronym, BP. BP is a virus that infects several species of both wild and cultured penaeid shrimp. It causes significant disease in the larval, postlarval and juvenile stages of the susceptible penaeid shrimp. Presently, BP-infected individuals are diagnosed by the presence of characteristic tetrahedral occlusion bodies (TOBs) observed microscopically in squash preparations of hepatopancreas, midgut or

\footnotetext{
- Addressee for correspondence
}

feces, or in histological sections (Couch 1974a, Lightner 1993).

Recombinant DNA techniques developed over the past decade have introduced new methods for diagnosis of viral diseases, based on the highly sensitive and specific hybridization of nucleic acid. One such method is in situ hybridization, which involves the utilization of DNA fragments obtained from the viral genome of interest. The DNA fragments are nonradioactively labelled to produce gene probes which specifically bind to viral nucleic acid located in infected cells. Using this method, disease detection is possible before the formation of occlusion bodies or observable cytopathology. This paper reports on the development of gene probes using DNA fragments obtained from the cloning of the BP genome.

\section{MATERIAL AND METHODS}

BP probes. Purification of BP DNA from free virions is described in detail in Bonami et al. (unpubl.) and Mari et al. (1993). Briefly, purification was achieved by homogenization of hepatopancreata from infected shrimp followed by low-speed centrifugation, Virions 
were isolated from the supernatant fluid by sequential centrifugation in 30 to $50 \%$ sucrose and 21 to $41 \%$ $\mathrm{CsCl}$ gradients. The free virions exhibited a buoyant density of $1.265 \mathrm{~g} \mathrm{ml}^{-1}$ (Bonami et al. unpubl.). The BP DNA used for cloning was obtained from the free virions using the procedure of Mari et al. (1993) wherein the virions were treated with proteinase $K$, followed by Sarkosyl, and the DNA then extracted with phenol, phenol-chloroform and chloroform-isoamyl alcohol, and precipitated with sodium acetate and ethanol.

The purified BP DNA was digested with the restriction endonuclease BamHI in order to obtain DNA fragments. The fragments were then ligated into BamHIdigested pUC 18 vector using T4 ligase. The resulting plasmids were used to transform competent DH5alpha $E$. coll bacterial cells. Plasmid purifications were performed on the transformed cells for preliminary screening of the clones obtained (Bonami et al. unpubl.). Five inserts from different areas of the genome were selected to perform initial testing as gene probes for in situ hybridization applications. The 5 probes were designated by the restriction endonuclease they were digested with ( $\mathrm{BamHI}=\mathrm{B}$ ) and their size (in $\mathrm{kbp}$ ). The clones were: B8.4A, B8.4B, B4.9, B3.9 and B1.23. Two of the inserts, B8.4A and B3.9, were digested with the restriction endonucleases HindIII and EcoRI respectively to yield DNA fragments under $1.0 \mathrm{kbp}$ that might serve as more effective probes. Inserts selected as potential gene probes were nonradioactively labelled with the Boehringer Mannheim Genius system (Indianapolis, IN, USA), which labels the DNA with digoxigenin, using the random prime method.

Tissue tested. Davidson's AFA or formalin-fixed tissue (Bell \& Lightner 1988) of BP-infected and uninfected shrimp from various geographical regions was tested using the 5 complete gene probes and the 2 digested probes separately, and combined as a equivolume mix. The species of BP-infected shrimp tested were Penaeus vannamei (Pacific white shrimp), P. stylirostris (Pacific blue shrimp) and $P$ aztecus (brown shrimp). BP infection of the shrimp was confirmed by demonstration of TOBs (also known as polyhedral inclusion bodies or PIBs) in histological preparations. $P$. vannamei and $P$. stylirostris tissues known not to be in.fected with BP were used as negative controls for the experiment. The probes were also tested on sections of shrimp tissue infected with the following viruses: infectious hypodermal and hematopoietic necrosis virus (IHHNV), hepatopancreatic parvo-like virus (HPV), $P$. monodon-type baculovirus (MBV), P. plebejus baculovirus (PBV), type $\mathrm{C}$ baculovirus of $P$ monodon (TCBV) (Lightner 1992) and yellow-head virus (YHV) (Anonymous 1992).

In situ hybridization procedure. For in situ hybridization, the tissue was preserved and processed using methods from Bell \& Lightner (1988). Specifically, preserved tissues were first embedded in ParaPlast Plus paraffin (Fisher Scientific) and sectioned at approximately $4 \mu \mathrm{m}$ thickness on a rotary microtome. Sections were placed onto positively charged microscope slides (Fisher Scientific) and were deparaffinized by heating for 30 to $45 \mathrm{~min}$ at $65^{\circ} \mathrm{C}$ followed by submersion in Hemo-De (Fisher Scientific), $3 \times$ for 5 min each. The sections were rehydrated by passing the slides through a series of graded alcohols (absolute to $50 \%$ ) and finally into distilled water. The slides were washed for 5 to $10 \mathrm{~min}$ in phosphate-buffered saline $(\mathrm{PBS} ; 1 \times=$ $0.137 \mathrm{M} \mathrm{NaCl}, 0.0027 \mathrm{M} \mathrm{KCl}, 0.0043 \mathrm{M} \mathrm{Na}_{2} \mathrm{HPO}_{4}$. $7 \mathrm{H}_{2} \mathrm{O}, 0.0014 \mathrm{M} \mathrm{KH}_{2} \mathrm{PO}_{4}, \mathrm{pH} 7.3$ ) at room temperature (RT; $25^{\circ} \mathrm{C}$ ). One $\mathrm{ml}$ of freshly prepared proteinase $\mathrm{K}$ at $100 \mu y \mathrm{nl}^{-1}$ in PBS was auded to each siide. The siides were incubated at $37{ }^{\circ} \mathrm{C}$ for $15 \mathrm{~min}$ in a humid chamber, then washed in $0.2 \%$ glycine in PBS for $10 \mathrm{~min}$ at RT, followed by a wash in $2 \times$ standard saline citrate (SSC; $1 \times=0.15 \mathrm{M} \mathrm{NaCl}, 0.015 \mathrm{M} \mathrm{Na}_{3}$ citrate, $\mathrm{pH} 7.0$ ) for $10 \mathrm{~min}$. One $\mathrm{ml}$ of hybridization buffer $[50 \%$ formamide, $0.02 \%$ Ficoll, $0.02 \%$ polyvinylpyrrolidone, $0.02 \%$ bovine serum albumen (BSA), $5 \%$ dextran sulfate, $4 \times \mathrm{SSC}, 0.5 \mathrm{mg} \mathrm{ml}^{-1}$ denatured salmon sperm DNA] was added to the slides, which were then incubated for 1.5 to $2 \mathrm{~h}$ at RT. Digoxigenin-labelled DNA probes, boiled for $10 \mathrm{~min}$ to denature the double strands and quenched on ice, were diluted to $10 \mathrm{ng}$ $\mathrm{ml}^{-1}$ in hybridization solution and $250 \mu \mathrm{l}$ was applied to each slide. A cover slip was placed on top, and the slides were placed in a boiling water bath covered with a piece of aluminum foil for $5 \mathrm{~min}$ to denature viral dsDNA in the tissue, after which they were incubated at $37^{\circ} \mathrm{C}$ overnight in a humid chamber.

After hybridization, the slides were washed in $2 \times$ $\mathrm{SSC}(1 \mathrm{~h}, \mathrm{RT}), 1 \times \mathrm{SSC}(1 \mathrm{~h}, \mathrm{RT})$, prewarmed $0.5 \times \mathrm{SSC}$ $\left(30 \mathrm{~min}, 37^{\circ} \mathrm{C}\right)$, and $0.5 \times \mathrm{SSC}(30 \mathrm{~min}, \mathrm{RT})$. The slides were equilibrated for 5 min in Buffer I (0.1 M Tris-HCI, $0.15 \mathrm{M} \mathrm{NaCl}, \mathrm{pH} 7.5$ ), then blocked with Buffer I containing $2 \%$ normal sheep serum and $0.3 \%$ Triton X-100 for $30 \mathrm{~min}$, at RT. Alkaline phosphatase-labeled sheep anti-digoxigenin antibody conjugate was diluted 1:5000 in Buffer I containing $1 \%$ normal sheep serum and $0.3 \%$ Triton $X-100$. Slides were incubated for 30 to $45 \mathrm{~min}$ at RT, in a humid chamber with $500 \mu \mathrm{l}$ of the diluted conjugate, then washed twice in Buffer I for $15 \mathrm{~min}$ each at RT. Slides were equilibrated in Buffer III (0.1 M Tris- $\mathrm{HCl}, 0.1 \mathrm{M} \mathrm{NaCl}, 0.05 \mathrm{M} \mathrm{MgCl}_{2}$, $\mathrm{pH}$ 9.5) for 5 min at RT. Color reagent was prepared by adding $2.4 \mathrm{mg}$ levamisole to $10 \mathrm{ml}$ Buffer III, along with the addition of $45 \mu \mathrm{l}$ nitroblue tetrazolium and $35 \mu l$ of 5-bromo-4-chloro-3-indoyl phosphate (both provided with Genius kit). Slides were incubated with $500 \mu \mathrm{l}$ of the color reagent overnight at RT in a humid chamber. 
After incubation, the reaction was stopped by washing the slides in Buffer IV $(0.01 \mathrm{M}$ Tris-HCl, $0.001 \mathrm{M}$

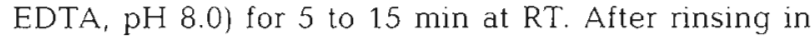
distilled water, the slides were dehydrated with a series of graded alcohols ( $50 \%$ to absolute), ending with immersion in Hemo-De. The slides were then mounted with a cover slip using a resinous mounting medium (Permount, Fisher Scientific). Each slide was examined, using normal bright field light microscopy, for cells displaying a dark blue to dark purple precipitate, indicating the presence of homologous BP DNA.

In attempts to optimize the reaction, the following parameters were altered: amount of probe added, amount of conjugate added, elimination of the boiling step after probe addition and addition of an $\mathrm{HCl}$ treatment step after tissue dehydration.

\section{RESULTS}

The BP genome used to make the inserts was originally purified from the hepatopancreata (HP) of BP-infected Penaeus vannamei obtained from a commercial shrimp farm in Hawaii. The stock had previously been imported from Ecuador. Each of the inserts selected and labelled as probes displayed a positive reaction to this 'source' tissue. However, since the original tissue contained very few TOBs and only small areas of precipitate were visible for any of the probes, a second positive control made from an infected $P$. vannamei from Ecuador was used to determine the effectiveness of the probes. This tissue contained a very heavy BP infection, with numerous TOBs clearly visible in the hepatopancreas. Each of the probes displayed a positive reaction to this tissue, although to varying degrees (Table 1).

No reaction was observed in BP-negative shrimp tissue (Fig. 1). Significantly, probe precipitate observed in BP-infected shrimp was confined to the HP (Fig. 2) and/or to the midgut epithelium (Fig. 3). No reactions to the probes were observed in any tissues other than the HP or midgut, a finding consistent with the conclusions of Couch (1974a) and Johnson \& Lightner (1988) that BP infections are limited to enteric tissues. The probes did not exhibit a reaction to shrimp tissue infected with any virus other than BP, such as IHHNV, HPV, MBV, PBV, TCBV or YHV (Table 2).

The TOBs found in BP-infected tissue frequently did not exhibit a distinct reaction to the probes (Fig. 4), but remained the same light brownish background color that was observed when no probe was added to BP-infected tissue. This was usually the case with the TOBs that had already erupted from the cells and were located in the tubules of the HP or in the lumen of the midgut. However, the purple precipitate, indicating a
Table 1 Reaction of BP probes to a heavily BP-infected Penaeus vannamei from Ecuador using in situ hybridization on paraffin sections of the hepatopancreas

\begin{tabular}{|c|c|c|c|}
\hline Probe & $\begin{array}{l}\text { Size } \\
\text { (kbp) }\end{array}$ & Intensity & Reaction description \\
\hline $\mathrm{B} 8.4 \mathrm{~A}$ & 8.4 & +++ & Moderate purple precıpitate \\
\hline $\mathrm{B} 8.4 \mathrm{~B}$ & 8.4 & +++ & Moderate purple precipitate \\
\hline B4.9 & 4.9 & + & $\begin{array}{l}\text { Some purple precipitate, } \\
\text { very light }\end{array}$ \\
\hline B3.9 & 3.9 & ++ & Light purple precipitate \\
\hline B1.23 & 1.23 & ++++ & Dark purple precipitate \\
\hline $\begin{array}{l}\mathrm{B} 8.4 \mathrm{~A} / \\
\text { HindIII }\end{array}$ & Varied & + & $\begin{array}{l}\text { Some purple precipitate, } \\
\text { very light }\end{array}$ \\
\hline $\begin{array}{l}\text { B3.9/ } \\
\text { EcoRI }\end{array}$ & Varied & + & $\begin{array}{l}\text { Very small amount of } \\
\text { purple precipitate }\end{array}$ \\
\hline
\end{tabular}

positive reaction for $\mathrm{BP}$ DNA, was often located in the same cells which formed TOBs and in some instances appeared to coat the outside of the TOBs (Fig. 5).

Intense reactions also occurred in individual cells that contained no TOBs. Sometimes these cells exhibited other signs of BP infection, such as isopynic nuclei and/or marginated chromatin (Lightner 1985), while in other instances a distinct positive reaction was demonstrated in cells that showed no observable signs of a BP infection (Fig. 6) except for possible slight hypertrophy. Presumably, these cells had very early infections and were in the eclipse stage of virogenesis.

The 5 undigested probes demonstrated mixed reactions when tested on BP-infected shrimp tissue from different geographical areas (Table 3). However, each BP-infected tissue section tested produced a positive reaction with a minimum of 2 of the probes. The probes $\mathrm{B} 1.23$ and $\mathrm{B} 8.4 \mathrm{~B}$ demonstrated positive reactions to all of the BP-infected tissue sections tested.

Alteration of parameters of the in situ hybridization procedure produced varied results. Increasing the

Table 2. Reaction of BP probes to Penaeus spp. shrimp tissue infected with viruses other than BP using in situ hybridization assays

\begin{tabular}{|llll|}
\hline Species & Origin & Virus & Reaction \\
\hline P. monodon & Asia & MBV & Negative \\
P. monodon & Australia & Type C & Negative \\
P. vannamei & Mexico & HPV & Negative \\
$P$. chinensis & Korea & HPV & Negative \\
$P$ plebejus & Australia & PBV & Negative \\
$P$ monodon & Thailand & YHV & Negative \\
$P$. monodon & Sri Lanka & YHV & Negative \\
$P$. stylirostris & Mexico & IHHN & Negative \\
& & & \\
${ }^{a}$ Lightner (1992) & & & \\
${ }^{b}$ Anonymous (1992) & & \\
\hline
\end{tabular}




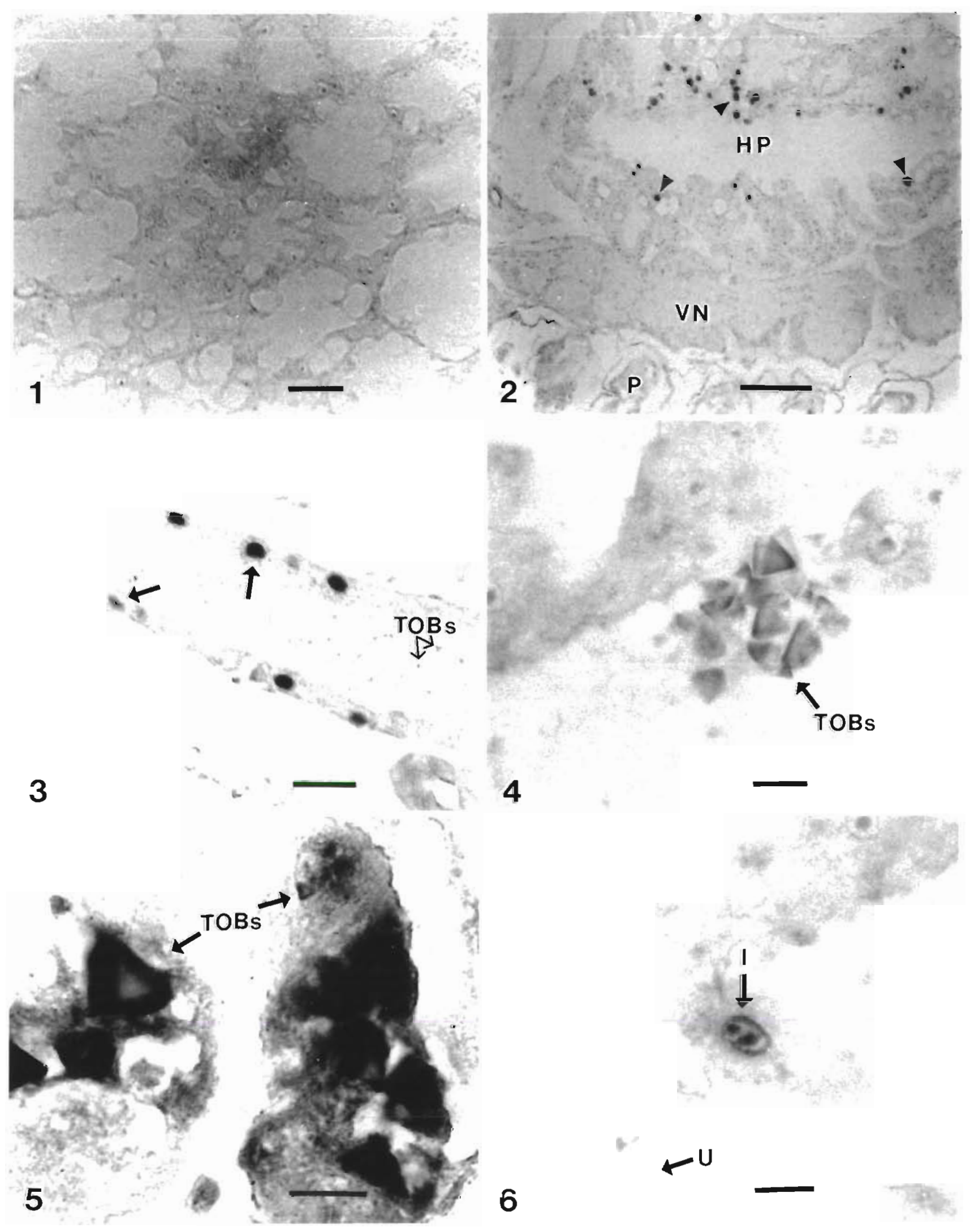


Table 3. Reaction of BP probes to various BP-infected Penaeus spp. tissue sections using in situ hybridization assays

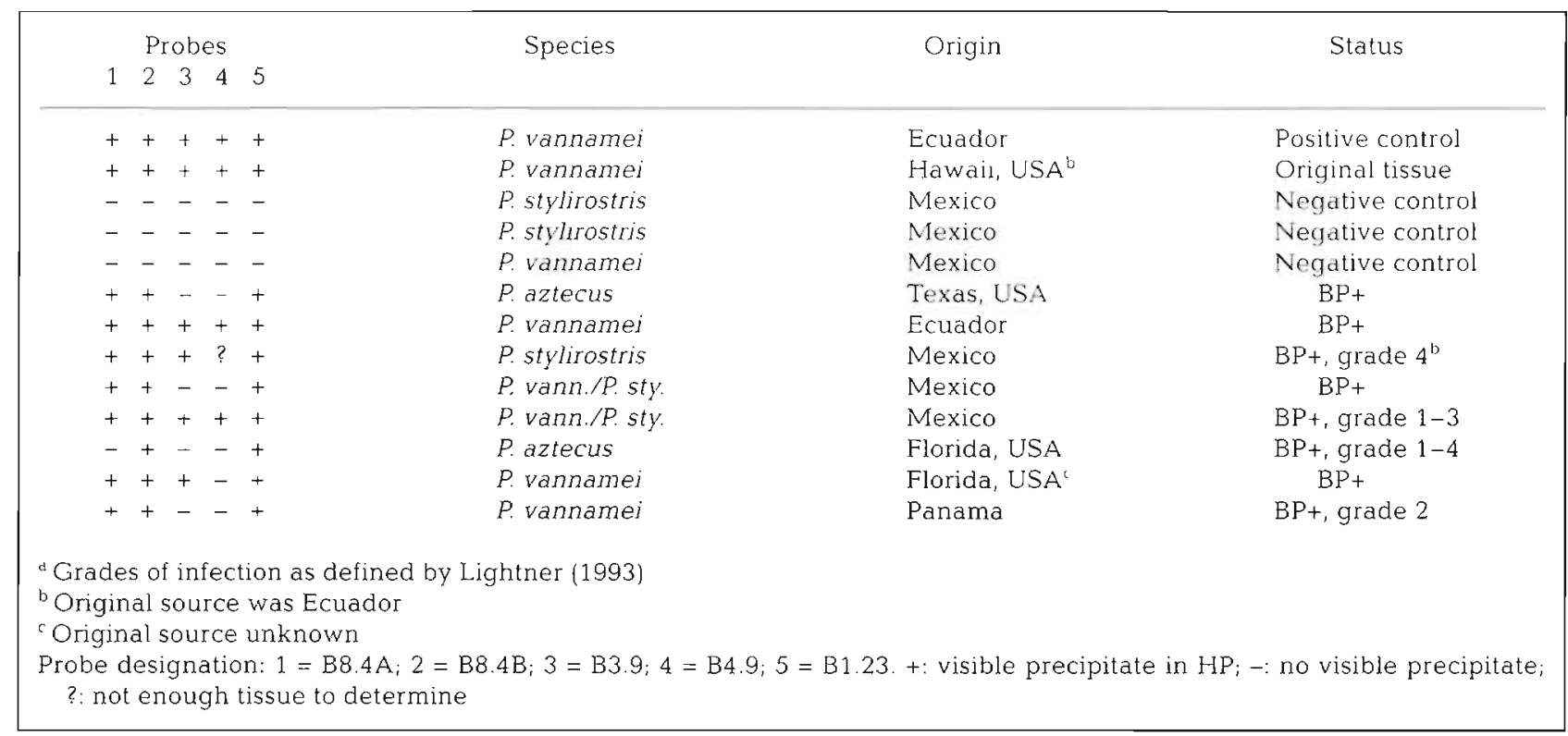

amount of probe from 2.5 to $12.5 \mathrm{ng}$ slide $^{-1}$ increased the intensity of the positive reaction observed, and the amount of precipitate present. However, increasing the amount of probe up to $25 \mathrm{ng}$ slide ${ }^{-1}$ or more did not improve the quality or intensity of the positive reaction achieved, and only increased the amount of background obtained for the reaction. Likewise, when the amount of antibody conjugate added was increased 10-fold, the intensity of the positive reaction remained about the same, but the amount of background increased significantly.

In another modification, positive reactions were substantially decreased both in quantity and intensity by eliminating the step where the cover-slipped sections were placed over the boiling water bath after addition of the probe, a step that denatures BP dsDNA and makes it more available to the probe. If the probe was added and the slide directly placed at $37^{\circ} \mathrm{C}$ for the overnight incubation, the positive reaction obtained was very inconsistent. If, after tissue rehydration, the slides were placed in $0.02 \mathrm{~N} \mathrm{HCl}$ for $10 \mathrm{~min}$ before pro- ceeding with the original protocol, the positive reaction was intensified, but there was also extensive tissue disruption which eliminated the positive reaction in some areas of tissue and made the value of such sections unsatisfactory.

\section{DISCUSSION}

The results demonstrate that gene probes to $\mathrm{BP}$ were successfully produced and that they can be used in a nonradioactive in situ hybridization assay to detect BP in paraffin-embedded, fixed tissue. Lack of a precipitate in BP-negative tissue demonstrates that the probes developed do not cross-react with shrimp tissue. Results also demonstrate that the probes tested do not cross-react with the other viruses tested, even with other shrimp-infecting baculoviruses. The 5 different probes tested in this study produced different intensities of reactions, even when applied to the same tissue. Thus, it can be concluded that some probes may be

Figs. 1 to 6. In situ hybridization of uninfected and BP-infected shrimp tissue, using an equivolume mix of the BP gene probes (no counterstain used). Fig. 1. Uninfected shrimp tissue demonstrating a complete absence of reaction in the hepatopancreas. Scale bar $=50 \mu \mathrm{m}$. Fig. 2. BP-infected shrimp tissue demonstrating a positive reaction (arrows) in cells of the hepatopancreas (HP), and no reaction in other tissues, such as those making up the ventral nerve cord (VN) and the periopods (P). Scale bar $=100 \mu \mathrm{m}$. Fig. 3. A positive reaction is visible in the epithelial cells lining the midgut of a BP-infected shrimp (arrows). TOBs present in the lumen of the midgut demonstrate no reaction. Scale bar $=25 \mu \mathrm{m}$. Fig. 4. Higher magnification micrograph of TOBs recently released from a necrotic cell into the lumen of a hepatopancreatic tubule. The TOBs lack probe precipitate as no free virus has remained available for reaction with the probe. Scale bar $=10 \mu \mathrm{m}$. Fig. 5 . Intact epithelial cells of the hepatopancreas containing TOBs coated with probe precipitate. Scale bar $=10 \mu \mathrm{m}$. Fig. 6 . Hepatopancreatic cell in a BP-infected shrimp demonstrating a positive reaction. The infected nucleus (I) is apparently in the eclipse phase of infection as the nucleoli are intact, nuclear hypertrophy is not apparent and TOBs are not yet forming. The nuclei of nearby uninfected cells (U) demonstrate no reaction with the probe. Scale bar $=10 \mu \mathrm{m}$ 
more effective than others. For example, Probe B1.23 consistently produced the most intense reaction, while Probes B3.9 and B4.9 produced the weakest. Probes made by digesting B8.4A and B3.9 with restriction endonucleases to produce DNA fragments smaller than $1.0 \mathrm{kbp}$ generated very weak reactions. However, the intensity of positive reactions did not correspond to the size of the probe, either directly or inversely. It is probable that the affinity of a probe for target nucleic acid depends primarily on its internal sequence.

Different tissue sections demonstrated varied intensities of reaction with the probes; however, the intensity appeared to be independent of the species of shrimp tested, the geographical origin of the shrimp and even the level of the infection (based on number of TOBs observed). These data would suggest that there are other factors influencing the reaction. One possible factor is the stage of virus replication, which would influence the quantity of viral DNA and mRNA available as target for the probe. The fact that TOBs in cell nuclei often had precipitate coating their surface indicates that viral nucleic acid was available for binding by the probes, presumably by virions embedded at or near the surface of the developing occlusion body, by areas of virogenic stroma or by accumulations of nonoccluded virions free in the nucleus. TOBs that had been released into the HP tubule and midgut lumen were presumably fully developed and did not have nucleic acid available for probe binding on their surfaces, as indicated by the overall lack of probe precipitate to them. Another possible factor could be the method or length of tissue fixation that was used. Higgs et al. (1990), using probes to detect human papillomavirus in tissue, reported that overfixing of cells led to a reduction of the hybridization signal. Since the tissue used in this experiment was usually obtained from commercial shrimp culture facilities who performed the fixation process, there was little control over the fixation procedure. Future experiments should be performed to test the effect of various fixatives and fixation times on the in situ hybridization results.

The ultrastructural aspects of virogenesis and cytopathology of BP-infected cells have been well described (Couch 1974a, b, 1989, 1991, Johnson \& Lightner 1988) and the findings of the present paper conform well to the observations made concerning virogenesis and cytopathology. Specifically, the probes detected BP nucleic acid in the nuclei of HP or midgut epithelial cells with early (eclipse) stage developing and fully developed BP infections.

Negative reactions demonstrated by probes to known BP-infected HP tissue sections were confirmed with a second testing of the same tissue. With only 1 exception, all the negative reactions demonstrated to known BP-infected tissue sections were obtained by
Probes B3.9 and B4.9. This is not surprising, since these 2 probes also exhibited the weakest reactions to the positive control tissues. The 1 exception was a negative reaction to demonstrated by Probe B8.4A to BP-infected Penaeus aztecus from Florida. The negative reaction was not species specific, since $\mathrm{B} 8.4 \mathrm{~A}$ demonstrated a positive reaction to $\mathrm{BP}$-infected $P$. aztecus from Texas. Both B3.9 and B4.9 also demonstrated a negative reaction to HPs from Texas-derived $P$. aztecus. The negative reactions could be a result of the fixation process, or, since $\mathrm{B} 8.4 \mathrm{~B}$ generally produced positive reactions only slightly stronger than B3.9 and B4.9, a result of poor probe binding. There is also the possibility that these results indicate that the tissues tested were infected with different strains of the BP virus. However, more extensive research, involving a larger databank of samples and testing more of the BP genome as probe, will need to be performed before this possibility can be evaluated. Since only known BPnegative and BP-positive tissue samples were used for this experiment, the question remains as to what stage the BP infection has to be in before detection of BP is possible by in situ hybridization. The most effective method of answering this question will be to monitor artificially infected postlarvae (Overstreet et al. 1988) using probes to BP. Samples taken at regular intervals after initial exposure to BP and subsequent analysis by histology and probe assays would illustrate when in situ detection of viral nucleic acid occurs compared to TOB development. However, the fact that positive reactions were evident in morphologically normal cells indicates the distinct possibility for early detection of $\mathrm{BP}$ infections.

The use of the polymerase chain reaction (PCR) to amplify BP DNA present in infected cells will further enhance the use of BP probes as diagnostic and research reagents. Techniques have been described in which amplification of nucleic acid in formalin-fixed, paraffin-embedded tissue is achieved using the PCR procedure (Nuovo et al. 1991). With the use of gene probes to BP, the capability may soon be developed to detect $B P$ in an infected batch of penaeid shrimp before contamination of culture facilities or wild stocks occurs. Thus, gene probes to $\mathrm{BP}$ appear to have considerable potential application as research tools and as diagnostic reagents.

Acknowledgements. This work was funded by grant \#NA90AA-D-SG545 from Sea Grant, U.S. Dept of Commerce, and by grant \#88-38808-3320 from the U.S. Dept of Agriculture, C.S.R.S. to the Gulf Coast Laboratory Marine Shrimp Farming Consortium. We also acknowledge James Brock at the Anuenue Fisheries Research Center, Aquaculture Development Program. Honolulu, Hawaii for assistance in obtaining samples. Thanks also to J. Mari and B Poulos for advice. 


\section{LITERATURE CITED}

Anonymous (1992). Yellow-head disease of black tiger shrimp. Asian Shrimp News, Asian Shrimp Culture Council, lssue no. 10, 2nd quarter, p. 2

Bell, T. A., Lightner, D.V. (1988). A handbook of normal penaeid shrimp histology. World Aquaculture Society, Baton Rouge

Couch, J. A. (1974a). An epizootic nuclear polyhedrosis virus of pink shrimp: ultrastructure, prevalence, and enhancement. J. Invertebr. Pathol. 24: 311-331

Couch, J. A. (1974b). Free and occluded virus similar to Baculovirus in hepatopancreas of pink shrimp. Nature 247 (5438): 229-231

Couch, J. A. (1989). The membranous labyrinthin baculovirus-infected crustacean cells: possible roles in viral reproduction. Dis. aquat. Org. 7: 39-53

Couch, J. A. (1991). Baculoviridae. Nuclear polyhedrosis Viruses. Part 2. Nuclear polyhedrosis virus of invertebrates other than insects. In: Adams, J. R., Bonami, J. R (eds.) Atlas of invertebrate viruses. CRC Press, Boca Raton, p. 205-225

Higgs, T. W., Moore, N. J., Badawi, D. X., Taub, F. E. (1990). Type-specific human papillomavirus detection in formalin-fixed, paraffin-embedded tissue sections using nonradioactive deoxyribonucleic acid probes. Lab. Invest. 63(4): 557-567

Johnson, P. T., Lightner, D.V. (1988). The rod-shaped nuclear

Responsible Subject Editor: J. E. Stewart, Dartmouth, N.S., Canada viruses of crustaceans: gut-infecting species. Dis. aquat. Org. 4: 123-141

Lightner, D. V. (1985). A review of the diseases of cultured penaeid shrimps and prawns with emphasis on recent discoveries and developments. In: Taki, Y., Primavera, T. H., Llobrera, $T$ A. (eds). Proceedings of the First International Conference on the Culture of Penaeid Prawns/ Shrimps, Iloilo City, Philippines, 2, p. 79-103

Lightner, D. V. (1992). Shrimp virus diseases: diagnosis, distribution, and management. In: Wyban, J. (ed.) Proceedings of the Special Session on Shrimp Farming. World A.quaculture Society, Baton Rouge

Lightner, D.V. (1993). Diseases of cultured penaeid shrimp. In: McVey, J. (ed.) CRC handbook of mariculture, Vol. 1, Crustacean aquaculture. CRC Press, Boca Raton, p. $393-486$

Mari, J., Bonami, J.-R., Poulos, B., Lightner, D. (1993). Preliminary characterization and partial cloning of the genome of a baculovirus from Penaeus monodon (PmSNPV = MBV). Dis. aquat. Org.16 (3): 207-215

Nuovo, G. J., MacConnell, P., Forde, A. (1991). Detection of human papillomavirus DNA in formalin-fixed tissues by in situ hybridization after amplification by polymerase chain reaction. Am. J. Pathol. 139 (4): 847-850

Overstreet, R. M., Stuck, K. C., Krol, R. A., Hawkins, W. E. (1988). Experimental infections with Baculovirus penaei in the white shrimp. Penaeus vannamei (Crustacea: Decapoda), as a bioassay. J. Wld Aquacult. Soc. 19: 175-187

Manuscript first received: June 4, 1993

Revised version accepted: August 3, 1993 